\title{
Faktor-faktor penentu dalam sejarah transformasi perwujudan Bangunan tinggal Bali aga
}

\author{
Ida Ayu Dyah Maharani, ${ }^{1}$ Imam Santosa, ${ }^{2}$ \\ Prabu Wardono, ${ }^{3}$ Widjaja Martokusumo ${ }^{4}$ \\ ${ }^{1}$ Institut Seni Indonesia Denpasar, \\ 1,2,3,4 Institut Teknologi Bandung \\ Email: dyahmaharani@isi-dps.ac.id
}

\begin{abstract}
Bali Aga residential buildings which have a vernacular character believed to be built deliberately by humans as a shelter when they started to live settled in 8th to 13th century. The shape of Bali Aga residential buildings have a transformation in similarity and difference among Bali Aga villages, occur in each period of Bali Aga era in diachronic ways. This research traces the factors which influence that phenomenon. The Bali Aga era that rebranding attempted to an ancient, the new and the newest Bali Aga, show that transformation in the similarity and difference is not due to cultural overlapping only. The change of local environmental conditions and potential also affect it, in accordance with the vernacular concept. Both become the most important factors affecting the shape of Bali Aga residential buildings, which written in qualitative historiography method limited to the discussion about interior and façade of buildings.
\end{abstract}

Keywords: defining factors, transformation, residential building shape, Bali Aga (Ancient Bali), historiography

\begin{abstract}
Abstrak
Bangunan tinggal Bali Aga yang memiliki karakter vernakular, diyakini merupakan bangunan yang sengaja dibangun oleh manusia untuk pertama kalinya sebagai tempat berteduh dan berlindung ketika mulai hidup menetap dalam kurun waktu abad ke-8 sampai dengan ke13. Wujud bangunan tinggal Bali Aga memiliki transformasi dalam kemiripan sekaligus perbedaan antar desa-desa Bali Aga, yang terjadi pada masing-masing kategori zaman Bali Aga secara diakronik. Penelitian ini menelusuri faktor-
\end{abstract}


faktor yang mempengaruhinya. Pembabakan zaman Bali Aga yang dilakukan menjadi zaman Bali Aga kuno, baru dan akhir, memperlihatkan bahwa transformasi wujud bangunan tinggalnya terjadi tidak hanya karena adanya tumpang tindih budaya. Perubahan kondisi dan potensi lingkungan setempat juga ikut mempengaruhi transformasi wujud bangunan tinggal sesuai dengan pemahaman konsep vernakular. Kedua hal tersebut menjadi faktor penting yang mempengaruhi transformasi wujud bangunan tinggal Bali Aga, yang dalam penulisan kualitatif bermetode sejarah ini dibatasi pada tata ruang dalam dan fasade bangunan.

Kata kunci: faktor penentu, transformasi, wujud bangunan tinggal, Bali Aga (Bali Kuno), sejarah

\section{Pendahuluan}

Deriodesasi sejarah Bali yang dilakukan Ardika dkk. (2013), 1 menyebutkan bahwa Bali Aga atau yang dikenal juga dengan Bali Kuno merupakan zaman yang meliputi kurun waktu antara abad ke-8 sampai dengan 13 di Bali. Zaman ini merupakan peralihan masa setelah berakhirnya zaman Bali Primitif yang cara hidup masyarakat masih nomaden, dan sebelum dimulainya zaman Bali Madya yang ditandai dengan kedatangan ekspedisi Gajah Mada dari Majapahit ke Bali. Bali Kuno dipimpin pertama kalinya oleh dinasti Singhamandawa, yang menurut Ardika (wawancara 10 April 2017) adalah sama dengan dinasti Warmadewa.

Pada zaman Bali Aga diyakini bahwa masyarakatnya mulai hidup menetap di suatu tempat dan bercocok tanam. Konsep hunian pada zaman Bali Aga ini mengingatkan pada pendapat Rapoport (1969) yang mengatakan bahwa pada awalnya, ketika manusia memulai hidup menetap, hunian dibuat sendiri dengan teknologi dan material sederhana, serta dengan cara lokal sebagai upaya pemenuhan kebutuhan manusia akan tempat berteduh dan berlindung dari kondisi alam lingkungan sekitarnya. Material bangunan diperoleh dari lingkungan sekitar tempat hunian didirikan sehingga tampilannya tampak menyatu dengan lingkungan. Penggunaan material, ruang dan penyelesaian akhir pengerjaannya memberikan wujud yang utuh sehingga hunian memiliki unsur originalitas dan memenuhi kebutuhan fungsional penghuninya (Rudofsky, 1964). Melalui tradisi yang dijalankan 
secara temurun serta upaya trial and error yang panjang, maka hunian ini bersifat timeless karena memiliki sustainability yang panjang, konstan dan spontan (Jackson, 1984 dalam Gartiwa, 2011).

Sebagian besar desa yang termasuk dalam kategori Bali Aga atau Bali Kuno, hingga kini masih dapat ditemui di dataran tinggi di Bali. Terlepas dari adanya keterkaitan dengan keyakinan kata 'Aga' yang berarti 'gunung', faktanya juga terdapat desadesa yang diklaim sebagai desa Bali Aga yang justru terletak di pinggir pantai dan dataran rendah lainnya, seperti Desa Julah (Buleleng) dan Tenganan Pegringsingan (Karangasem). Rekaman data terhadap beberapa desa Bali Aga terpilih yang menjadi lokasi penelitian, menunjukkan adanya kemiripan dan juga perbedaanperbedaan dalam wujud hunian antar desa-desa Bali Aga. Hal ini memunculkan sebuah asumsi adanya transformasi di dalamnya dan memiliki faktor-faktor tertentu yang mempengaruhinya. Seperti yang disebutkan dalam hasil penelitian Parimin (1986), bahwa karakter desa-desa Bali Aga tersebut mengalami perubahanperubahan.

Beberapa penelitian telah pernah dilakukan dengan objek kasus hunian Bali Aga, baik berupa penataan permukiman, sistem spasial dan sebagainya. Berbagai metode penelitian juga telah pernah digunakan, seperti etnografi, fenomenologi, hermeneutik dan deskriptif kualitatif. Namun, penelitian-penelitian tersebut sebagian besar terfokus pada salah satu desa Bali Aga saja dan berulang kembali diakukan pengamatan pada desa yang sama. Hasil penelitian pada satu desa Bali Aga tertentu pun seringkali digunakan untuk mengeneralisir secara luas tentang hunian Bali Aga, seolah sama pada desa-desa Bali Aga lainnya.

Untuk melengkapi hasil-hasil penelitian yang telah ada, artikel ini bertujuan untuk menelusuri lebih lanjut apa yang menjadi transformasi wujud bangunan tinggal Bali Aga beserta faktor-faktor yang mempengaruhinya. Tujuan ini dicapai melalui sebuah sudut pandang kualitatif yang bermetode sejarah, dengan melakukan penelusuran secara diakronik dan sinkronik dalam rentang waktu masa lalu abad ke-8 sampai dengan 13. Penelitian ini dicoba dilakukan pada sebagian besar desa Bali Aga (tersebar di kabupaten Bangli, Buleleng dan Karangasem), dengan memilih beberapa desa yang mewakili masing-masing kategori desa Bali 
Aga.

Pada desa Bali Aga yang terpilih dari masing-masing kategori sebagai lokasi penelitian (Tabel 1), diambil satu fokus objek penelitian berupa bangunan tinggalnya, dan pembahasan dibatasi pada tata ruang dalam dan fasade bangunan (penggunaan material dan proporsi bangunan tinggal).

Tabel 1. Desa-desa Bali Aga sebagai lokasi penelitian

\begin{tabular}{|c|c|c|}
\hline KABUPATEN BANGLI & $\begin{array}{c}\text { KABUPATEN } \\
\text { BULELENG }\end{array}$ & $\begin{array}{c}\text { KABUPATEN } \\
\text { KARANGASEM }\end{array}$ \\
\hline $\begin{array}{l}\text { KECAMATAN KINTA- } \\
\text { MANI: } \\
\text { Sukawana, Belandingan, } \\
\text { Belantih, Belanga, Binyan, } \\
\text { Batukaang, Mengani, Ca- } \\
\text { tur, Manikliyu, Lembean, } \\
\text { Langgahan, Bunutin, Ulian, } \\
\text { Awan, Serahi, Bayung } \\
\text { Gede, Mangguh, Belancan. } \\
\text { KECAMATAN BANGLI: } \\
\text { Pengotan, Penglipuran }\end{array}$ & $\begin{array}{l}\text { KECAMATAN } \\
\text { BANJAR: } \\
\text { Sidatapa, Cem- } \\
\text { paga, Tigawasa, } \\
\text { Pedawa. } \\
\text { KECAMATAN } \\
\text { KUBUTAMBA- } \\
\text { HAN: } \\
\text { Julah }\end{array}$ & $\begin{array}{l}\text { KECAMATAN } \\
\text { MANGGIS: } \\
\text { Tenganan Pe- } \\
\text { gringsingan }\end{array}$ \\
\hline
\end{tabular}

Sumber: dokumentasi penulis, 2017

\section{Pengkategorian Desa Bali Aga Berdasarkan Sumber Sejarah}

Sumber sejarah yang banyak menceritakan tentang sejarah Bali Aga adalah berupa prasasti yang sebagian besar ditulis di atas logam (daripada batu atau tanah liat). Prasasti yang pertama kali menyebutkan angka tahunnya adalah prasasti Sukawana AI yaitu 804 Caka (882 Masehi) yang di dalamnya menyebutkan nama Singhamandawa yang diyakini sebagai nama kerajaan Bali Kuno. Selain prasasti tersebut, kerajaan ini juga memiliki enam prasasti lainnya yang berbahasa Bali Kuno yaitu prasasti Bebetin AI (818 Caka), Trunyan AI (833 Caka), Trunyan BI (833 Caka), Bangli Pura Kehen A, Gobleg Pura Desa I (836 Caka), dan Angsari A; yang tidak satupun di antaranya menyebut nama rajanya. Ketujuh prasasti tersebut menunjukkan bahwa desa-desa yang tersebut 
sebagai nama prasasti tersebut memang sudah ada sejak zaman Bali Kuno.

Menurut Ardika (wawancara 10 April 2017), dengan adanya banyak peninggalan yang ditemukan maka pergerakan penyebaran desa-desa Bali Aga diperkirakan berawal dari Pejeng dan Bedulu menuju ke desa-desa seperti yang tersebut dalam prasasti-prasasti dari zaman Singhamandawa, yaitu Sukawana dan Trunyan. Perkembangannya kemudian terdiri dari beberapa jalur. Pertama, Sukawana, Belandingan dan sekitarnya. Kedua, ke arah Desa Bantang, Dausa dan sekitarnya. Ketiga, ke arah deretan desa Daup, Selulung, Pangejaran, Belantih, Bantang, Binyan, Batukaang, Mengani dan Catur. Keempat, deretan Desa Manikliyu, Langgahan, Lembean, Bunutin, Ulian, Gunungbau, Awan dan Serahi. Kelima, desa-desa Bali Aga di pinggiran danau Batur seperti Trunyan, Songan, dan sekitarnya. Keenam, perkembangan ke jalur Bayung Gede, Bayung Cerik, Bukih, Belancan, Mangguh. Terakhir, perkembangan menuju ke arah Pengotan dan Penglipuran (diyakini merupakan perkembangan Desa Bayung Gede).

Pada masa-masa berikutnya muncullah sebutan dinasti Warmadewa, yang menurut isi sebuah prasasti Blanjong (836 Caka) bahwa pengaruh Bali Kuno meliputi hingga Bali selatan yaitu Sanur (Wikarman, 2013). Prasasti Julah menyebutkan bahwa dinasti Warmadewa pada zaman raja Ugrasena juga memiliki pengaruh di Bali Utara (Buleleng), yaitu sekitar daerah Julah, Peminggir, Buhun Dalem, Purwasiddi, dan Manasa. Pusat pemerintahan dinasti Warmadewa diyakini berakhir di daerah Singadwala (Pejeng, Gianyar). Dinasti tersebut beberapa penduduknya di kemudian hari ada yang berhijrah ke Karangasem, tepatnya di Desa Tenganan (wawancara dengan I Wayan Yudistira, 2 September 2016). Tentang penyebaran masyarakat Bali Aga, lihat Gambar 1. 


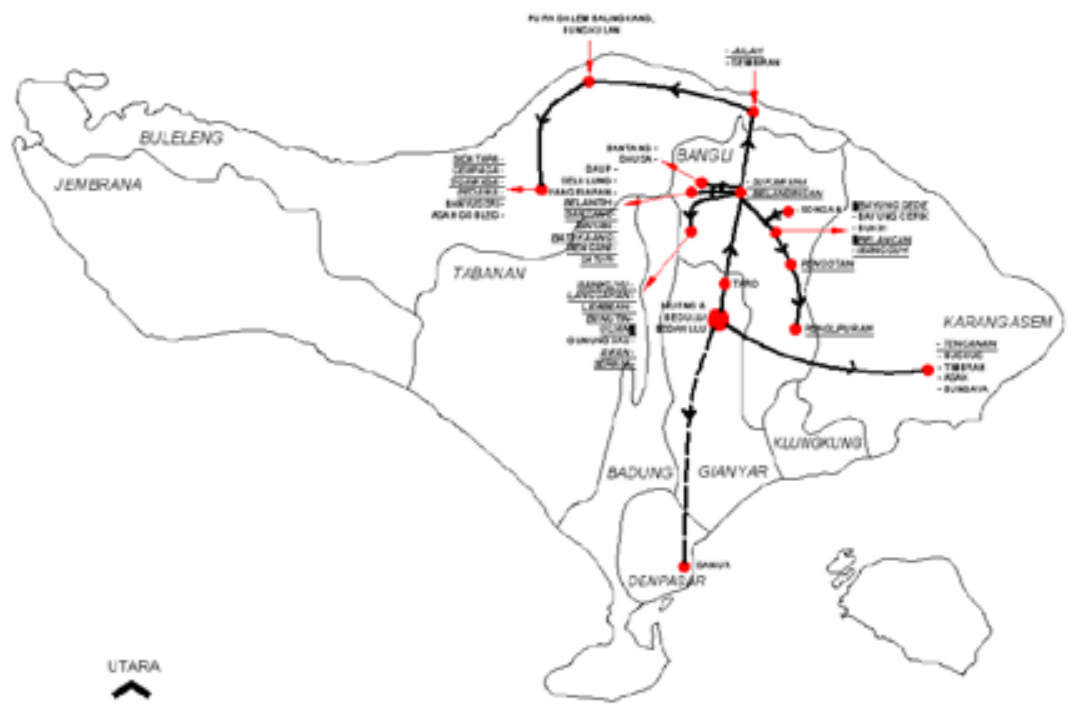

Gambar 1 Pergerakan desa-desa Bali Aga dalam sejarah Sumber: modifikasi Street Atlas Bali, 2016

Catatan sejarah dalam prasasti-prasasti tersebut memperlihatkan adanya hubungan di antara desa-desa Bali Aga yang terdapat di Kabupaten Bangli, Buleleng dan Karangasem. Dapat disimpulkan bahwa desa-desa Bali Aga yang berada di daerah Kintamani dan Buleleng cenderung termasuk kategori Bali Aga yang berumur lebih awal, tua atau kuno. Perkembangannya kemudian menuju ke arah Bangli selatan membentuk desa-desa Bali Aga lainnya seperti desa Bayung Gede dan Penglipuran, yang dapat dikategorikan sebagai desa Bali Aga baru. Berdasarkan catatan sejarah, kepemimpinan dinasti Warmadewa ini berakhir di daerah Singadwala, Gianyar dan banyak masyarakatnya yang berhijrah ke desa Tenganan Pegringsingan, Karangasem yang juga dapat dikategorikan sebagai desa Bali Aga akhir (lihat Tabel 2). 
Tabel 2 Pengkategorian desa-desa Bali Aga berdasarkan derajat usianya

\begin{tabular}{|l|l|l|}
\hline \multicolumn{1}{|c|}{ AWAL/TUA/KUNO } & \multicolumn{1}{|c|}{ BARU } & \multicolumn{1}{|c|}{ AKHIR } \\
\hline $\begin{array}{l}\text { Sukawana, Belandingan, Belantih, Be- } \\
\text { langa, Binyan, Batukaang, Mengani, Catur, } \\
\text { Manikliyu, Lembean, Langgahan, Bunutin, } \\
\text { Ulian, Awan, Serahi, Mangguh, Belancan, } \\
\text { Pengotan, Sidatapa, Cempaga, Tigawasa, } \\
\text { Pedawa, Julah }\end{array}$ & $\begin{array}{l}\text { Bede, } \\
\text { Penglipuran }\end{array}$ & $\begin{array}{l}\text { Ten- } \\
\text { ganan Pe- } \\
\text { gringsin- } \\
\text { gan }\end{array}$ \\
\hline
\end{tabular}

Sumber: dokumentasi penulis, 2017

\section{Transformasi Wujud Bangunan Tinggal}

\subsection{Tata Ruang Dalam Bangunan Tinggal}

Menurut Gartiwa (2011) bangunan yang tergolong vernakular memiliki hubungan yang kuat dengan lingkungannya (selain dengan manusia dan kebudayaannya) seperti yang tersebut dalam Social System Approach. Sebagian besar desa Bali Aga berada di dataran tinggi dengan suhu udaranya yang dingin, sehingga penghuninya masih membutuhkan penghangat ruangan berupa tungku tradisional di dalam bangunannya. Namun, dari hasil pengamatan awal yang dilakukan oleh penulis pada lokasi beberapa desa Bali Aga terpilih, terdapat empat jenis lingkungan sekitar desadesa Bali Aga berada yaitu hutan (cemara dan bambu), perkebunan (seperti jeruk, kopi dan sayuran), laut dan perbukitan yang berada dekat dengan pantai. Keempat jenis lingkungan tersebut memiliki suhu lingkungan yang berbeda, maka terdapat perbandingannya fasilitas penghangat ruang tradisional (tungku) seperti yang dapat dilihat pada Tabel 3. 
Tabel 3 Perbandingan keberadaan tungku dalam bangunan tinggal di desa-desa Bali Aga yang terpilih sebagai lokasi penelitian

\begin{tabular}{|c|c|c|c|}
\hline $\begin{array}{l}\text { HUTAN } \\
\text { (KINTA- } \\
\text { MANI \& } \\
\text { BANGLI) }\end{array}$ & $\begin{array}{c}\text { PERKEBUNAN } \\
\text { (KINTAMANI \& BAN- } \\
\text { GLI) }\end{array}$ & $\begin{array}{l}\text { LAUT } \\
\text { (BULE- } \\
\text { LENG) }\end{array}$ & $\begin{array}{l}\text { PERBUKITAN } \\
\text { DEKAT PANTAI } \\
\text { (BULELENG \& } \\
\text { KARANGASEM) }\end{array}$ \\
\hline $\begin{array}{l}\text {-Sukawana: } \\
\text { ada tungku } \\
\text {-Bayung } \\
\text { Gede: ada } \\
\text { tungku } \\
\text {-Pengli- } \\
\text { puran: ada } \\
\text { tungku }\end{array}$ & $\begin{array}{l}\text {-Belandingan: ada } \\
\text { tungku } \\
\text {-Belantih: ada tungku } \\
\text {-Belanga: ada tungku } \\
\text {-Binyan: ada tungku } \\
\text {-Batukaang: ada tungku } \\
\text {-Mengani: ada tungku } \\
\text {-Catur: ada tungku } \\
\text {-Manikliyu: ada tungku } \\
\text {-Langgahan: ada tungku } \\
\text {-Lembehan: ada tungku } \\
\text {-Bunutin: ada tungku } \\
\text {-Ulian: ada tungku } \\
\text {-Awan: ada tungku } \\
\text {-Serai: ada tungku } \\
\text {-Belancan: ada tungku } \\
\text {-Mangguh: ada tungku } \\
\text {-Pengotan: ada tungku }\end{array}$ & $\begin{array}{l}\text { Julah : } \\
\text { tungku } \\
\text { terpisah } \\
\text { dengan } \\
\text { bangunan } \\
\text { utama }\end{array}$ & $\begin{array}{l}\text {-Sidatapa: ada } \\
\text { tungku } \\
\text {-Cempaga: ada } \\
\text { tungku } \\
\text {-Tigawasa: ada } \\
\text { tungku } \\
\text {-Pedawa: ada } \\
\text { tungku } \\
\text {-Tenganan Pe- } \\
\text { gringsingan: } \\
\text { tungku terpisah } \\
\text { dengan bangunan } \\
\text { utama }\end{array}$ \\
\hline
\end{tabular}

Sumber: dokumentasi penulis, 2016

Pada awalnya, masyarakat Bali Aga hanya memerlukan satu massa bangunan saja sebagai tempat tinggalnya. Sebagian besar ruang dalam bangunan tinggal Bali Aga kuno terbagi menjadi enam bagian (berdasarkan banyaknya tampul yang berjumlah 12). Dua bagian (sekitar 32\% dari luasan) untuk bale tempat tidur, satu bagian untuk dapur tradisional (sekitar 16\% dari luasan), satu bagian khusus untuk ruang suci (sekitar 16\% dari luasan) dan satu bagian untuk sirkulasi (16\% dari luasan). Perkembangannya pada desa-desa Bali Aga kategori baru, pembagian ruang dalam hanya terbagi menjadi tiga yaitu ruang tidur dan dapur tradisional (masing-masing sekitar 40\% dari luasan) dan sirkulasi (sekitar 20\% dari luasan) (Lihat Gambar 2). Sedangkan pada desa Bali Aga akhir, justru keberadaan dapur sudah terpisah dari bangunan tinggal utama seperti yang terdapat di desa Tenganan Pegringsingan. 


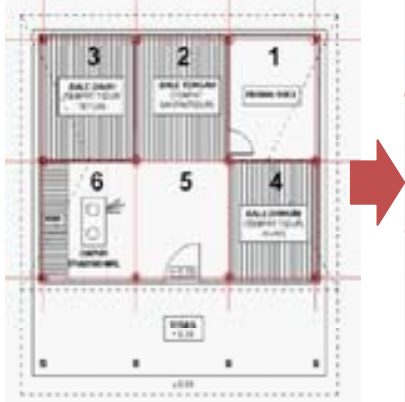

(a)

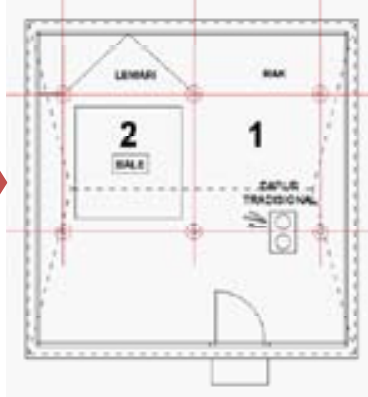

(b)

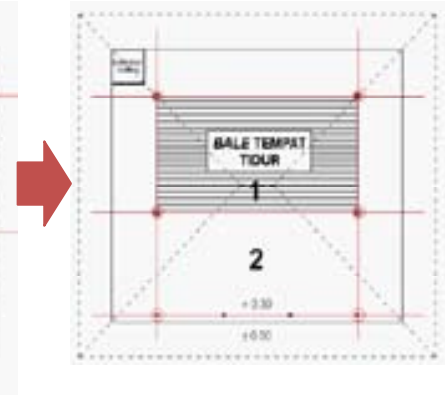

(c)

Gambar 2 Transformasi persentase pembagian tata dan fungsi ruang dalam bangunan tinggal, dari Bali Aga Kuno di desa Mengani (a), Bali Aga baru di desa Bayung Gede (b) dan Bali Aga akhir di desa Tenganan Pegringsingan (c) Sumber: dokumentasi penulis, 2016

Pada Tabel 3 memperlihatkan bahwa dari 26 desa hanya dua desa yang memiliki ruang dapur terpisah dengan ruang tidurnya (tidak berada dalam satu bangunan), yaitu desa Julah dan Tenganan Pegringsingan. Dalam wawancara dengan penduduk setempat terungkap bahwa pada awalnya Julah juga memiliki bangunan tinggal yang pertama kali dibangun seperti desa-desa Bali Aga lainnya yaitu yang memiliki dapur tradisional dan ruang tidur dalam satu bangunan (I Wayan Jaya, 22 Desember 2014, 23 Januari 2016 dan 5 Juli 2016; serta I Ketut Sidemen, 5 Juli 2016). Perkembangannya, area dapur tradisional menjadi terpisah dengan bangunan berikutnya yang dibangun sebagai ruang tidur yang disebut bale meten. Hal ini terjadi sebagai upaya adaptasi, bahwa Julah berada di pinggiran pantai dengan suhu udara yang cenderung panas (lihat Gambar 3). 


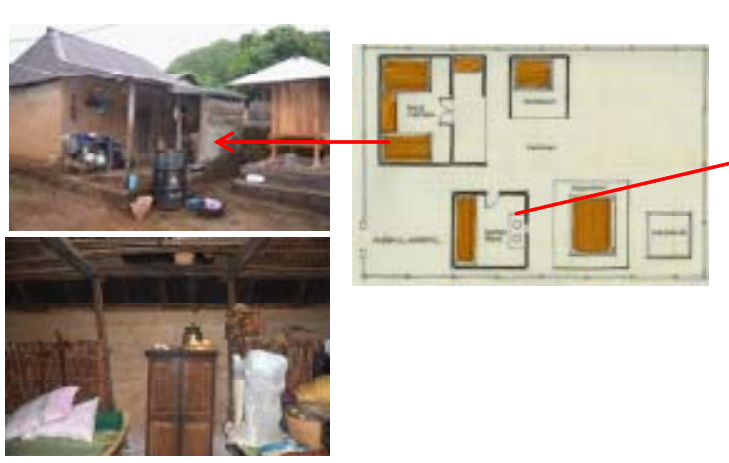

Bale meten (ruang tidur)

(a) (b)

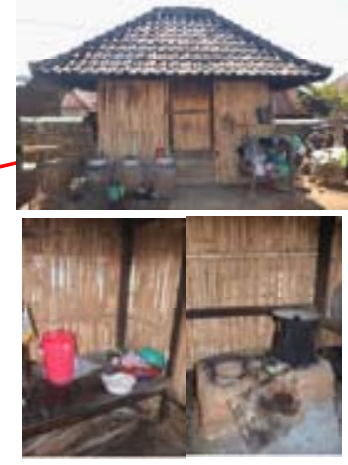

Paon (dapur)

(c)

Gambar 3 Salah satu penataan bangunan tinggal di desa Julah (b), bangunan pertama yang dibangun kini hanya berfungsi sebagai dapur berdinding anyaman bambu (c), kemudian ruang tidur menjadi bangunan terpisah yang disebut bale meten berdinding tanah popolan (a)

Sumber: dokumentasi penulis, 2016 dan Remawa, 2006

Selain pergeseran keberadaan dapur tradisional, Gambar 2 juga memperlihatkan adanya pergeseran keberadaan ruang suci yang semula menjadi satu dalam bangunan tinggal menjadi ke luar bangunan tinggal secara terpisah. Hal ini juga menyebabkan jumlah tampul terutama pada bangunan tinggal Bali Aga kategori baru pun menjadi berkurang. Seperti bangunan tinggal yang terdapat di Desa Penglipuran (lihat Gambar 4), memiliki tampul berjumlah enam yang membagi ruang dalam menjadi bagian bale, dapur dan sirkulasi.

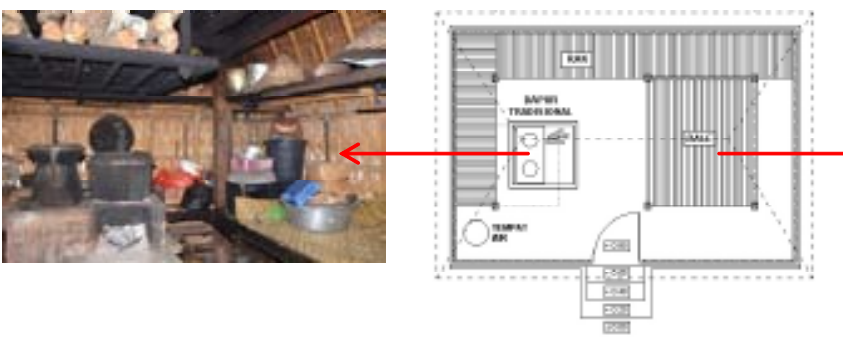

(a)

(b)

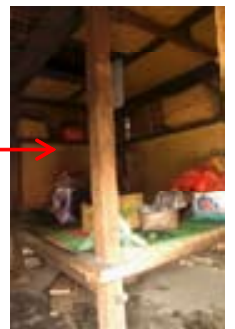

(c)

Gambar 4 Tata ruang dalam bangunan tinggal di Penglipuran, Bangli

(b) yang terbagi menjadi ruang dapur tradisional (a), bale meten (c) dan sirkulasi. Keberadaan ruang suci sudah menjadi ruang yang terpisah dengan bangunan utama.

Sumber: dokumentasi penulis (2016) 
Pada desa Bali Aga akhir yaitu Tenganan Pegringsingan, enam tampul membagi menjadi dua ruang yaitu bale dan sirkulasi masingmasing sekitar $40 \%$ dan $60 \%$ dari luasan bangunan tinggal. Hal ini disebabkan karena dalam bangunan tinggalnya tersebut sudah tidak memiliki ruang yang berfungsi sebagai dapur tradisional dan ruang suci lagi (lihat Gambar 5). Dalam rentetan sejarahnya, desa Tenganan Pegringsingan merupakan desa Bali Aga kategori akhir yang kemunculannya mendekati masa masuknya periode Bali Madya. Hunian Bali Madya memiliki banyak massa tunggal yang terpisah dengan masing-masing fungsinya. Terpisahnya dapur dan ruang tidur tidak dalam satu bangunan, diduga bukan karena merupakan hasil proses adaptasi dengan lingkungannya saja namun juga sebagai dampak masuknya pengaruh Arsitektur Bali Madya.

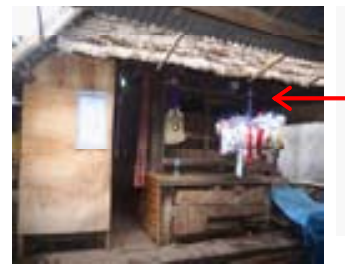

Bale meten (ruang tidur)

(a)

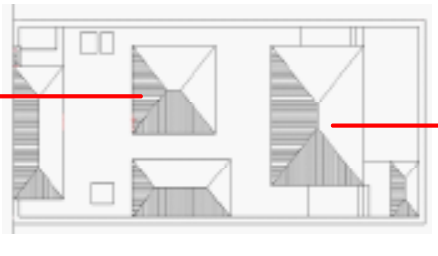

Paon (dapur) dan ruang lain

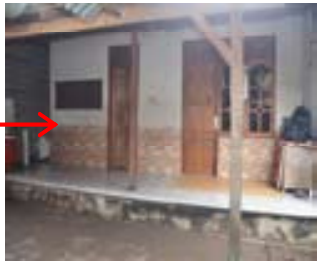

(c)

Gambar 5 Penataan hunian pada salah satu pekarangan di desa Tenganan

Pegringsingan, Karangasem (b) yang memiliki bangunan tinggal yang berfungsi sebagai ruang tidur (a), dapur (c) dan ruang suci yang terpisah

Sumber: dokumentasi penulis, 2016

\subsection{Penggunaan Material pada Fasade Bangunan Tinggal}

Terdapat adanya dua jenis material dinding yang dominan digunakan pada bangunan tinggal Bali Aga (lihat Tabel 4), yang keduanya diperoleh dari lingkungan sekitarnya yaitu bambu dan kayu yang berasal dari pepohonan serta tanah popolan (liat). Tidak banyak bangunan tinggal Bali Aga yang menggunakan material tanah popolan, kecuali hanya di Julah (pada bale meten), Sidatapa dan Tigawasa. Tanah popolan, seperti halnya bata, memiliki sifat masif (jika dibandingkan dengan material dinding lainnya berupa bambu dan kayu) sehingga dapat menyimpan hangat dalam ruangan. Sidatapa dan Tigawasa, keduanya merupakan desa yang 
terletak di dataran tinggi perbukitan, walaupun tidak terlalu jauh dari pantai Lovina, Buleleng.

Berbeda halnya dengan Julah yang berada tepat di pinggir pantai dengan suhu udara yang lebih panas. Maka dapat dilihat disini, bahwa masyarakat Julah walaupun menggunakan tanah popolan sebagai material dinding bale meten sebagai ruang tidur namun keberadaannya dipisahkan dari dapur tradisional sehingga mengurangi panas dalam ruang. Sebaliknya, dalam bangunan tinggal di Sidatapa dan Tigawasa masih dapat dijumpai keberadaan tungku, karena masyarakat masih membutuhkannya untuk dapat menciptakan rasa hangat dalam ruangan sebagai akibat lokasi desa yang berada di daerah dataran tinggi.

Tabel 4. Perbandingan penggunaan material bangunan tinggal di desa-desa Bali Aga yang terpilih sebagai lokasi penelitian

\begin{tabular}{|c|c|c|c|}
\hline $\begin{array}{l}\text { HUTAN (KIN- } \\
\text { TAMANI \& } \\
\text { BANGLI) }\end{array}$ & $\begin{array}{c}\text { PERKEBUNAN } \\
\text { (KINTAMANI \& BAN- } \\
\text { GLI) }\end{array}$ & $\begin{array}{l}\text { LAUT } \\
\text { (BULE- } \\
\text { LENG) }\end{array}$ & $\begin{array}{c}\text { PERBUKITAN } \\
\text { DEKAT PANTAI } \\
\text { (BULELENG \& } \\
\text { KARANGASEM) }\end{array}$ \\
\hline $\begin{array}{l}\text {-Sukawana: } \\
\text { dinding papan } \\
\text {-Bayung Gede: } \\
\text { dinding bambu } \\
\text {-Penglipuran: } \\
\text { dinding bambu }\end{array}$ & $\begin{array}{l}\text {-Belandingan: dinding } \\
\text { bambu } \\
\text {-Belantih: dinding bambu } \\
\text {-Belanga: dinding bambu } \\
\text {-Binyan: dinding bambu } \\
\text {-Batukaang: dinding } \\
\text { bambu } \\
\text {-Mengani: dinding bambu } \\
\text {-Catur: dinding bambu } \\
\text {-Manikliyu: dinding } \\
\text { bambu } \\
\text {-Langgahan: dinding } \\
\text { bambu } \\
\text {-Lembehan: dinding papan } \\
\text {-Bunutin: dinding papan } \\
\text {-Ulian: dinding papan } \\
\text {-Awan: dinding papan } \\
\text {-Serai: dinding papan } \\
\text {-Belancan: dinding papan } \\
\text {-Mangguh: dinding papan } \\
\text {-Pengotan: dinding bambu }\end{array}$ & $\begin{array}{l}\text { Julah : dind- } \\
\text { ing bambu } \\
\text { (pada paon) } \\
\text { dan tanah } \\
\text { popolan pada } \\
\text { bale meten }\end{array}$ & $\begin{array}{l}\text {-Sidatapa: dinding } \\
\text { tanah popolan } \\
\text {-Cempaga: dinding } \\
\text { bambu } \\
\text {-Tigawasa: dinding } \\
\text { tanah popolan } \\
\text {-Pedawa: dinding } \\
\text { bambu } \\
\text {-Tenganan Pe- } \\
\text { gringsingan: terbuka } \\
\text { dengan kelambu }\end{array}$ \\
\hline
\end{tabular}

Sumber: dokumentasi penulis, 2016 
Selain ketiga desa tersebut, mayoritas desa-desa Bali Aga yang menggunakan anyaman bambu dan papan sebagai material dindingnya dapat dijumpai di dataran tinggi seperti Kintamani dan Bangli yang bersuhu dingin. Sifat dinding anyaman bambu dan papan kayu tidak bisa menyimpan dingin walaupun dengan pemasangan yang sangat rapat. Maka dalam bangunan-bangunan tersebut seringkali dapat ditemukan dapur tradisional dengan tungku. Tidak adanya sekat antara ruang dapur dengan ruangan lainnya, membuat panas dari tungku mampu menghangati seluruh ruangan. Asap dari tungku dikeluarkan melalui celah anyaman bambu pada dinding. Anyaman bambu juga digunakan sebagai material plafon, sehingga asap juga bisa keluar lewat atap. Untuk bangunan tinggal yang berdinding dari papan, biasanya selalu memiliki bukaan jendela. Hal ini disebabkan, pasangan papan selalu lebih rapat daripada anyaman bambu sehingga celah sebagai lubang tempat keluarnya asap menjadi lebih sedikit.

Pada bagian atap, dulunya juga banyak yang menggunakan material dari sekitarnya seperti sirap bambu. Adanya kelangkaan material bambu tersebut, menyebabkan masyarakat mulai menggunakan alternatif material lainnya yaitu genteng tanah dan seng. Beberapa desa tertentu, seperti yang disampaikan oleh Parma (2016) dari desa Sidatapa, sangat menghindari penggunaan material atap genteng tanah karena berasal dari tanah (yang berada di bawah). Jika tanah digunakan sebagai material atap (yang berada di bagian atas), sedangkan di dalam bangunan tinggal terdapat ruang suci, maka dianggap tulah. Pemilihan material seng sebagai material penutup atap adalah sebagai solusi. Kini, hal tersebut bukan lagi untuk bisa menghindari tulah tapi menjadi solusi sebagai akibat kelangkaan material kayu dan bambu dari lingkungan sekitarnya. Material seng yang bersifat sebagai konduktor panas, dapat menyimpan hangat lebih maksimal pada siang hari. Simpanan panas atau hangat tersebut dirasakan manfaatnya dengan baik ketika pada malam hari karena pada saat itu di area gunung menjadi lebih cepat dingin daripada lembah sebagai akibat kehilangan radiasinya.

Masyarakat Bali Aga, seperti halnya masyarakat vernakular lainnya, lebih banyak menggunakan material bangunan yang diperoleh dari lingkungan sekitarnya, walaupun terkadang dari sifat-sifat material yang digunakan kurang sesuai dengan suhu 
udara di tempat tersebut. Reaksi adaptasi yang diambil adalah dengan melakukan gubahan ruang dan unsur pembentuknya dengan fungsi tertentu untuk dapat menciptakan kenyamanan dalam bangunan tinggalnya. Adanya perubahan sebagai akibat kelangkaan material dari alam, pada beberapa desa masih sangat memperhatikan nilai-nilai kepercayaan tertentu dalam pemilihan bahan bangunan barunya. Namun seiring dengan perkembangan zaman, nilai-nilai tersebut sudah mulai diabaikan dan tergantikan dengan fungsi praktis.

\subsection{Sistem Proporsi Bangunan Tinggal}

Bangunan tinggal Bali Aga dapat dikategorikan sebagai bangunan vernakular, yang seperti dikatakan oleh Wright dalam Oliver (2003) bahwa bangunan tersebut muncul dan tumbuh sebagai respon dari kebutuhan dasar yang sebenarnya. Segala pengetahunan cara membangun pada saat itu, hingga kini belum didapatkan panduan tertulisnya (tidak seperti halnya panduan cara membangun pada zaman Bali Madya yang diturunkan dalam lontar Asta Kosali dan Asta Bumi). Bukti sejarah yang ditemukan di beberapa desa Bali Aga adalah berupa prasasti yang banyak membahas mengenai wilayah kekuasan (karena pada zaman tersebut terdapat kerajaan Bali Kuno), pajak, hak dan kewajiban rakyat. Sedangkan lontar Asta Kosali dan Asta Bumi muncul pada zaman Bali Aga akhir, mendekati abad ke-14. Bangunan tinggal di beberapa desa Bali Aga yang kemunculannya mendekati abad ke-14, banyak yang mengklaim telah menerapkan sistem dimensi gegulak seperti yang termuat dalam lontar Asta Kosali dan Asta Bumi dalam proses pembangunannya.

Masyarakat Bali Aga dari periode awal hingga kini selalu memandang bumi sebagai suatu kehidupan. Pandangan seperti itu membawa sikap tunduk pada alam bagi masyarakat primitif, sikap hormat pada alam bagi masyarakat vernakular dan tradisional. Di Bali, pegunungan dianggap sebagai tempat suci yang penuh dengan ketenangan, dataran permukiman sebagai tempat aktifitas kehidupan manusia, serta laut sebagai tempat pembuangan akhir dan penghanyutan dari segala sisa yang ada di bumi. Hal tersebut bisa disamakan dengan pembagian tubuh manusia yaitu kepala sebagai pusat panca indera, badan sebagai pusat aktifitas kerja dan kaki sebagai penerus berat badan ke bumi. Bangunan tinggal Bali 
Aga pun dibagi dengan pembagian atap yang diibaratkan sebagai bagian kepala, tiang dan dinding sebagai badan, serta lantai pondasi atau bebaturan sebagai kaki.

Sebagian besar desa Bali Aga masih dapat dijumpai di daerahdaerah pegunungan, yang merupakan area yang dianggap suci bagi sebagian besar masyarakat Bali (Reuter, 2005). Penghormatan yang sangat dalam terhadap alam semesta dengan menganggapnya sebagai Bhuana Agung, maka kesucian alam pun dibawa ke dalam wujud bangunan tinggalnya. Bangunan-bangunan tinggal yang dijumpai saat ini di beberapa desa Bali Aga, masih dapat terlihat adanya nilai-nilai filosofi penghormatan terhadap alam tersebut. Di bagian ruang dalam bangunan tinggalnya selalu dapat ditemukan suatu ruang khusus yang disucikan oleh penghuninya. Beberapa dimensi juga dibuat dengan berintiusi makna filosofi di balik pembuatannya.

Pada perkembangan periode Bali Aga selanjutnya, terutama ketika sudah mendekati periode Bali Madya yang sangat banyak mendapatkan pengaruh Majapahit, untuk mencapai kualitas estetis bangunan maka dalam menciptakan bangunan tinggal Bali Aga tidak hanya mengandalkan intuisinya saja dalam mengambil keputusan, namun berupaya mencari pedoman yang konsisten melalui ukuran-ukuran bagian tubuh seperti telapak tangan dan jari. Dalam bagian ini dikenal beberapa istilah pengukuran tradisional Bali yang disebut dengan gegulak seperti yang termuat dalam aturan Asta Kosali dan Asta Bumi dengan masing-masing nama pada anggota tubuh manusia yang merupakan panduan dalam menetapkan ukuran bangunan pada bagian interior maupun wujud luar bangunan. Masyarakat Bali Aga yang selalu percaya bahwa antara manusia dan tempatnya itu laksana Bhuana Alit dan Bhuna Agung yang merupakan kesatuan yang harmonis (Bidja, 2000). Maka dengan berpedoman dengan gegulak dipercaya dapat menghindarkan para penghuninya dari hal-hal yang bersifat negatif.

Menurut Remawa (2015), gegulak ini juga dibuat untuk memenuhi tuntutan-tuntutan manusia Bali terhadap ukuran-ukuran yang diinginkan dalam merancang bangunan. Ukuran-ukuran arsitektural maupun elemen-elemen interiornya dicari dengan menggunakan perbandingan proporsi dimensi tubuh manusia (antroposentris), seperti yang disebutkan oleh Reuter (2002): 
The house is at once a dwelling place for embodied human beings and an analogy of a body, for the body itself is regarded as the house of the soul (atma, urip). This analogy is made explicit in determining the proportion of house...derived directly from the bodily proportion of its initial owner.

Pengukuran dengan gegulak ini menggunakan ukuran tubuh penghuninya, yang biasanya diambil dari ukuran tubuh lakilaki yang berperan sebagai kepala keluarga. Kemudian masingmasing ukuran ini dicoba untuk diterjemahkan dalam standar metrik. Laki-laki menjadi kepala keluarga dipilih sebagai rujukan dalam pengukuran bangunan tinggalnya karena di Bali masih menganut sistem patrilinear yang mengganggap laki-laki memiliki kedudukan tertinggi dalam sebuah keluarga (jika dilihat secara antroposentris, ukuran tubuh laki-laki memang sebagian besar lebih besar dibandingkan dengan ukuran tubuh perempuan). Penggunaan ukuran tubuh laki-laki dapat menciptakan suatu bangunan tinggal beserta elemen-elemen yang dimensinya juga dapat digunakan oleh perempuan dan anak-anaknya. Sistem dimensi pada satu bangunan tinggal akan menjadi berbeda dengan bangunan tinggal lainnya karena berdasarkan hasil pengukuran kepala keluarga yang berbeda. Walaupun dimensi gegulak dapat diterjemahkan dalam satuan centimeter, tapi dimensi ini tidak bisa distandarisasikan karena sangat tergantung dengan ukuran struktur tubuh masing-masing kepala keluarga. Cara pengukuran dengan gegulak ini menciptakan karakter yang sangat khas pada bangunannya dan sangat berbeda dengan karakter bangunan pada arsitektur Barat.
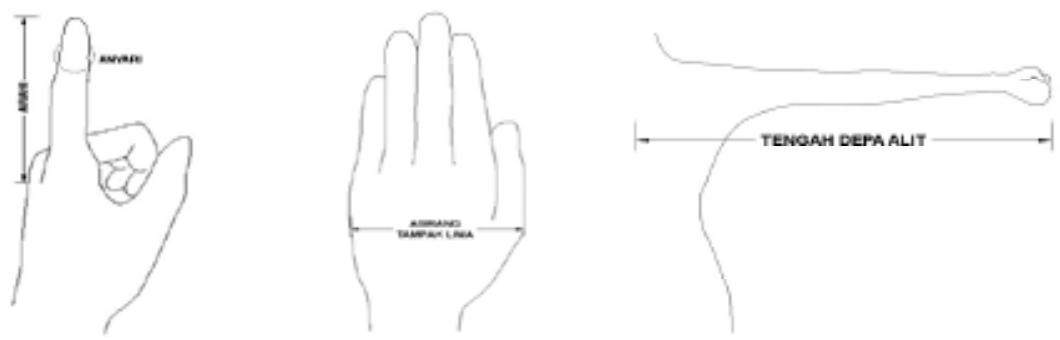

Gambar 6 Beberapa teknik pengukuran dengan menggunakan anggota tubuh manusia

Sumber: modifikasi dari Bidja, 2000 


\subsubsection{Proporsi bukaan terhadap bidang dinding}

Pada bangunan tinggal Bali Aga selalu memiliki lubang pintu dengan dimensi lebar sekitar $60 \mathrm{~cm}$ dan tinggi sekitar 120-150 cm (lihat Gambar 7). Dibandingkan dengan dimensi struktur tubuh manusia (standar ukuran tubuh orang Asia) yang memiliki tinggi tubuh sekitar $175 \mathrm{~cm}$, membuat penghuni harus membungkuk terlebih dahulu ketika melewati lubang pintu baik ketika masuk maupun keluar rumah. Konon hal ini mengandung filosofi bahwa ketika masuk ke rumah harus dengan sikap tubuh membungkuk untuk menghormati pemilik rumah dan isinya (karena dalam bangunan tinggal Bali Aga juga terdapat ruang khusus yang disucikan). Sehingga bangunan tinggal Bali Aga dengan ukuran lubang pintu cenderung kecil pada periode awal ini dianggap sebagai bangunan yang memiliki karakter sakral.

Patut diingat juga bahwa periode Bali Aga merupakan periode setelah Bali primitif dimana manusianya pada saat itu hidup secara nomaden di gua-gua yang mereka temui di alam liar. Maka pada sebagian besar bangunan tinggal Bali Aga ini dapat ditemui bagian bebaturan (bagian bawah dari bangunan) yang sangat tinggi sekitar 50-60 cm. Beberapa hal lainnya semacam ini pun dapat ditemui di daerah-daerah lainnya di Indonesia, seperti adanya rumah pohon (bangunan tinggal yang sengaja dibangun di atas pohon besar) dan rumah panggung (bangunan tinggal yang didirikan di atas tiangtiang, dimana pada bagian bawah bangunan dibiarkan sebagai ruang kosong).

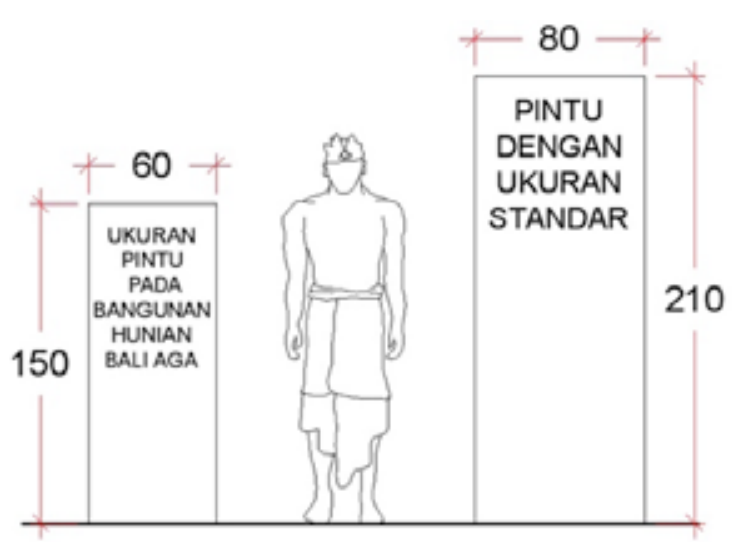

Gambar 7 Perbandingan dimensi lubang pintu pada bangunan Bali Aga (kiri) dan yang telah menggunakan standarisasi ukuran pintu (kanan)

Sumber: dokumentasi penulis (2016) 
Bangunan tinggal Bali Aga awal cenderung tertutup, hanya memiliki satu bukaan saja yang berupa lubang pintu berukuran kecil. Jika dihitung proporsi ukuran pintu yang berukuran lebar $60 \mathrm{~cm}$ dan tinggi $150 \mathrm{~cm}$ terhadap bidang dinding yang berukuran sekitar lebar $350 \mathrm{~cm}$ dan tinggi $150 \mathrm{~cm}$, maka lubang tersebut hanya $17 \%$ dari bagian bidang dindingnya. Untuk kebutuhan ventilasi, pada awalnya hanya memanfaatkan lubang-lubang kecil pada anyaman bambu sebagai bahan dinding dan sirap bambu sebagai bahan penutup atap.

Dengan perkembangan zaman, material dinding pun mulai berubah sebagai akibat dari semakin sedikitnya ketersediaan bahan alam. Kemudian muncullah keberadaan dua jendela (terutama untuk bangunan tinggal yang berdinding papan kayu), dengan ukuran sekitar lebar $60 \mathrm{~cm}$ dan tinggi $80 \mathrm{~cm}$. Adanya tambahan dua jendela tersebut maka proporsi bukaan terhadap bidangnya menjadi sekitar 35\%. Kecilnya angka perbandingan luas bukaan terhadap dindingnya, mengindikasikasikan masyarakat Bali Aga telah paham bagaimana beradaptasi dengan lingkungan yang desadesa ini memang mayoritas berada di dataran tinggi (pegunungan) dengan temperatur udara yang dingin.

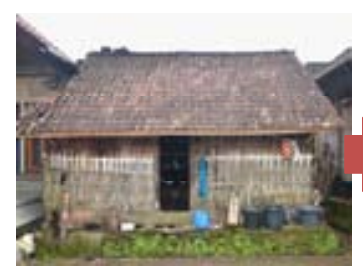

(a)

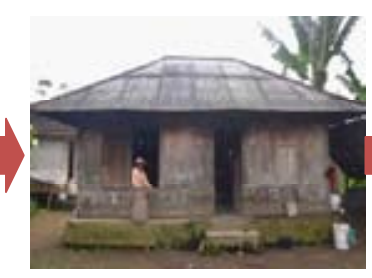

(b)

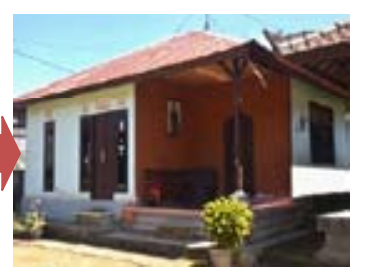

(c)

Gambar 8 Dimensi bangunan tinggal Bali Aga awal (a) dengan proporsi bukaan lebih kecil jika dibandingan pada bangunan tinggal Bali Aga pada periode-periode berikutnya (b-c) Sumber: dokumentasi penulis (2016)

\subsubsection{Proporsi denah dan tinggi bangunan}

Tidak semua bagian dari bangunan tinggal Bali Aga menggunakan sistem gegulak sebagai pedoman dalam pengukuran. Masyarakat Bali Aga tidak hanya mengandalkan intuisinya dalam mengambil sebuah keputusan dalam membangun. Pada periode Bali Aga baru dan terakhir yang merupakan peralihan menuju Bali Madya, gegulak dalam Asta Kosali dan Asta Bumi mulai digunakan 
namun belum diterapkan sepenuhnya. Terkadang dimensi suatu elemen juga sangat tergantung dengan jenis dan ukuran material bangunan yang digunakan.

Sebagai contoh yang terdapat di Desa Bayung Gede, menurut Jero Kabayan Pemucuk setempat (2015), bahwa penentuan jarak antar saka (tampul atau tiang) tergantung dari dimensi penampang bahan yang digunakan. Cara menghitungnya adalah jarak saka untuk bale sama dengan jarak saka pada ruang paon (dapur) ditambah dengan duang saka (dalam bahasa Bali duang berarti dua sehingga maksudnya adalah 2x lebar penampang saka). Bahan tiang yang sering digunakan adalah bambu atau kayu dengan dimensi penampang $9 \times 9 \mathrm{~cm}$ atau $10 \times 10 \mathrm{~cm}$, maka jika lebar area dapur 175 $\mathrm{cm}$ dan lebar penampang bahan saka yang digunakan adalah $10 \mathrm{~cm}$ maka lebar bale adalah $175 \mathrm{~cm}+(2 \times 10 \mathrm{~cm})$ menjadi sekitar $195 \mathrm{~cm}$ (lihat Gambar 9). Sedangkan penentuan ukuran ketinggian ruang dalam (jarak lantai ke plafon) adalah selikur rai ditambah dengan pengurip (dalam bahasa Bali selikur berarti 21). Maksudnya adalah 21xlebar bahan saka yang digunakan ditambah dengan pengurip. Jika menggunakan tiang dari bahan yang berukuran $9 \times 9 \mathrm{~cm}$ maka ketinggian ruang dalam adalah sekitar $21 \times 9 \mathrm{~cm}=189 \mathrm{~cm}$. Untuk menentukan ketinggian elemen pelengkap ruang dalam seperti ketinggian bale, maka caranya adalah tinggi total dari saka tersebut dibagi menjadi dua bagian yaitu $1 / 3$ darinya menjadi dimensi ketinggian bale yang diukur dari lantai (sekitar $60 \mathrm{~cm}$ ) dan 2/3 darinya adalah jarak bagian atas bale ke plafon.

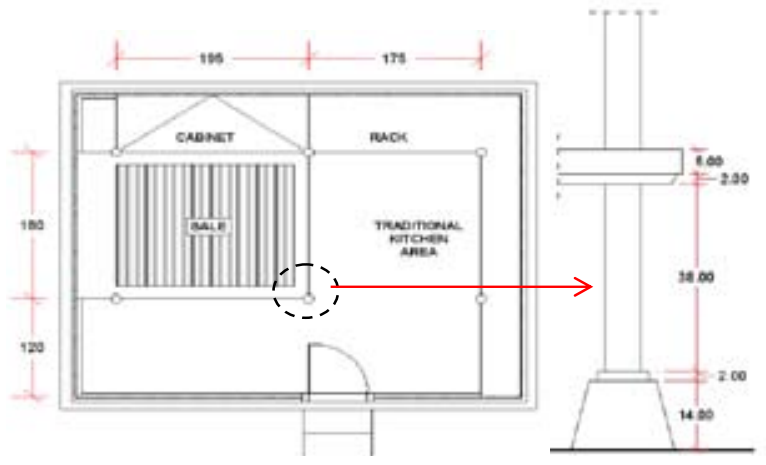

(a)

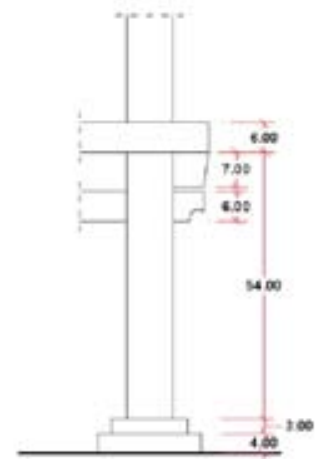

(b)

Gambar 9 Jarak pada tata letak saka dalam ruang dalam (a) dan alternatif penentuan ketinggian bale dari lantai pada bangunan tinggal Bali Aga (b)

Sumber: dokumentasi penulis (2016) 
Penjelasan sistem dimensi yang dipergunakan pada sebagian besar bangunan tinggal Bali Aga tersebut memperlihatkan lebih banyak menggunakan dimensi struktur tubuh manusia sebagai rujukannya. Masyarakat Bali Aga beranggapan bahwa tubuh manusia sebagai mikrokosmos yang tak ubahnya seperti alam semesta namun dalam skala terkecil, sehingga hal ini juga merupakan upaya dalam mendekatkan diri dengan alam semesta. Walaupun pengamatan yang dilakukan oleh orang-orang masa kini beranggapan bahwa bangunan tinggal Bali Aga terlihat kecil dan sederhana ukurannya (lihat Tabel 5), namun bagi masyarakat Bali Aga sebagai penghuninya menganggap rumah sebagai bentuk penyederhanaan alam semesta yang dianggap suci dan penuh makna filosofi.

Tabel 5 Perbandingan dimensi pada bangunan tinggal Bali Aga

\begin{tabular}{|l|c|c|c|}
\hline \multicolumn{1}{c|}{$\begin{array}{c}\text { SISI-SISI YANG } \\
\text { DIBANDINGKAN }\end{array}$} & $\begin{array}{c}\text { PERBANDIN- } \\
\text { GAN ANGKA }\end{array}$ & $\begin{array}{c}\text { PESI- } \\
\text { MAL } \\
\text { INGAN DEN- } \\
\text { GAN GOLDEN } \\
\text { RATIO }\end{array}$ \\
\hline \hline Lebar / panjang bangunan & $375 / 360$ & 1,04 & $<1,618$ \\
\hline $\begin{array}{l}\text { Lebar / tinggi } \\
\text { dinding+bebaturan bangu- } \\
\text { nan }\end{array}$ & $375 / 160$ & 2,34 & $>1,618$ \\
\hline $\begin{array}{l}\text { Lebar / tinggi atapbangunan } \\
\text { Panjang / tinggi } \\
\text { dinding+bebaturan bangu- } \\
\text { nan }\end{array}$ & $375 / 220$ & 1,70 & $\sim 1,618$ \\
\hline $\begin{array}{l}\text { Panjang / tinggi atap ban- } \\
\text { gunan }\end{array}$ & $360 / 220$ & 1,63 & $>1,618$ \\
\hline Tinggi / panjang bangunan & $388 / 375$ & 1,03 & $<1,618$ \\
\hline Tinggi / lebar bangunan & $388 / 360$ & 1,07 & $<1,618$ \\
\hline Luas bidang / luas bukaan & $45000 / 7200$ & 6,25 & $>1,618$ \\
\hline
\end{tabular}

Sumber: dokumentasi penulis, 2016 
Hasil perbandingan angka-angka memperlihatkan bahwa angka Golden Ratio didapat dari perbandingan masing-masing lebar dan panjang bangunan terhadap tinggi atap bangunan yang menghasilkan angka mendekati 1,618. Angka-angka perbandingan lainnya menghasilkan angka mendekati satu, seperti perbandingan antara panjang dan lebar bangunan, tinggi dengan panjang atau dengan lebar bangunan. Hal ini mengindikasikan bahwa bangunanbangunan tinggal Bali Aga memiliki kecenderungan berbentuk bujur sangkar sama sisi baik secara horisontal (denah bangunan) maupun vertikal (dengan tinggi bangunan).

Sistem dimensi pada zaman Bali Aga memiliki tiga cara pengukuran dilihat dari perkembangannya. Pertama adalah pada awal periode Bali Aga, sistem dimensi yang dibuat berdasarkan simbolisasi pemaknaan. Kedua, sistem dimensi yang digunakan sangat tergantung pada dimensi material yang tersedia di alam sekitarnya, seperti dimensi kayu dan bambu. Ketiga, ketika memasuki periode akhir Bali Aga menuju Bali Madya, ditemukan sistem dimensi dengan gegulak (yaitu ukuran bangunan disesuaikan dengan ukuran tubuh). Gegulak memiliki kesamaan dengan konsep antroposentris yang menjadikan manusia sebagai pusat pengukurannya (namun yang menjadi rujukan ukuran adalah ukuran tubuh laki-laki sebagai kepala keluarga).

Menurut Suryajaya (2016), pada zaman Vitruvius pun sudah diciptakan sistem pengukuran antroposentris, seperti jarak ujung dagu ke ujung dahi = jarak pergelangan tangan ke ujung jari tengah = sepersepuluh tinggi badan manusia, dan sebagainya. Sistem dimensi yang merujuk pada Golden Ratio juga memiliki persamaan dengan konsep antroposentris, namun yang membedakannya adalah bahwa sistem dimensi Golden Ratio memiliki dimensi fungsi, menciptakan sistem dimensi kebutuhan terhadap ruang gerak manusia dalam beraktifitas sehingga menjadi ukuran standar internasional. Sedangkan sistem dimensi Bali Aga menggunakan dimensi tubuh manusia yang lebih mengutamakan nilai filosofi (kepercayaan, teosentris).

\section{Simpulan}

Transformasi kemiripan dan perbedaan pada wujud bangunan tinggal di antara desa-desa Bali Aga dipengaruhi oleh dua hal. Pertama adalah pengaruh tumpang tindih budaya dari zaman 
sebelum atau sesudahnya yang membawa pengaruh tersendiri pada wujud bangunan tinggal Bali Aga. Contohnya, aturan dalam lontar Asta Kosali dan Asta Bumi mempengaruhi perwujudan bangunan tinggal Bali Aga yang muncul hampir bersamaan di akhir abad ke13 atau awal abad ke-14.

Kedua, kondisi dan potensi lingkungan bangunan tinggal. Kondisi lingkungan terutama suhu udara, membuat masyarakat di lingkungan tersebut beradaptasi dengan menciptakan tata ruang dalam yang berwujud pada pengolahan jenis massa bangunan, material yang digunakan dan proporsi bangunan. Desa Bali Aga yang sebagian besar dapat dijumpai di dataran tinggi, masih memiliki satu bangunan tunggal dengan penaataan dan fungsi ruang yang lebih kompleks. Sedangkan desa-desa Bali Aga yang terletak di dataran rendah, masyarakatnya tidak memerlukan penghangat ruang sehingga area dapur pun kemudian menjadi massa bangunan yang terpisah dari bangunan utama.

Potensi lingkungan pun ikut mempengaruhi wujud bangunan tinggal Bali Aga. Sesuai dengan konsep vernakular, material bangunan yang digunakan adalah yang tersedia di lingkungan sekitarnya. Hal ini kemudian tercermin dari keragaman material bangunan tinggal Bali Aga yang menggunakan bahan bambu, kayu ataupun tanah popolan.

\section{DAFTAR PUSTAKA}

Anonim. 2003. Bali Street Atlas 2003-2004 edition. Singapore: Periplus

Ardika, I W., Parimartha, I G., dan Wirawan, A.A.B. 2013. Sejarah Bali dari Prasejarah Hingga Modern. Denpasar: Udayana University Press

Bidja, I Md. 2000. Asta Kosala-Kosali Asta Bumi. Denpasar: Pustaka Bali Post

Gartiwa, M. 2011. Morfologi Bangunan dalam Konteks Kebudayaan. Bandung: Penerbit Muara Indah

Mantra, I. B. dan Kasto. 1985. Penentuan Sampel, dalam Singarimbun, M. dan Effendi, S.. Metode Penelitian Survai. Jakarta: LP3ES

Oliver, P. 2003. Dwellings (The Vernacular House World Wide). New York: Phaidon 
Parimin, A.P. 1986. Environmental Hierarchy of Sacred - Profan Concept in Bali

Rapoport, A. 1969. House Form and Culture. Englewood Cliffs NJ: Prentice Hall Inc.

Remawa, A.A. Gd. R. 2015. Konsep Estetika dan Ruang pada Gubahan Bangunan tinggal Bali Madya. Institut Teknologi Bandung: Disertasi Program Doktor

Reuter, T.A. 2002. The House of Our Ancestors. Nederlands: KITLV Press

Reuter, T.A. 2005. Custodians of The Sacred Mountains (Budaya dan Masyarakat di Pegunungan Bali). Jakarta: Yayasan Obor Indonesia

Rudofsky, B. 1964. Architecture Without Architecture (A Short Introduction to Non-Pedigreed Architecture). New York: Museum of Modern Art, New York

Suryajaya, M. 2016. Sejarah Estetika (Era Klasik sampai Kontemporer). Jakarta: Gang Kabel dan Indie Book Corner

Wikarman, I Nym. S. 2013. Bangli Tempo Doeloe (Dalam Kajian Sejarah). Bangli: Yayasan Wikarman 